\title{
SHORT REVIEW OF IMMUNOTHERAPY TOXICITY
}

\author{
IVANA CANJKO ${ }^{1}$, LUKA PERIĆ ${ }^{1,2}$, JOSIPA FLAM ${ }^{1,2}$, MAJA KOVAČ BARIĆ ${ }^{1}$, \\ DARKO KOTROMANOVIĆ ${ }^{1,2}$ NORA PUŠELJIĆ ${ }^{2,3}$ and MIRELA ŠAMBIĆ PENC ${ }^{1,2}$ \\ ${ }^{1}$ Department of Oncology, University Hospital Center Osijek, Osijek, Croatia; \\ ${ }^{2}$ Faculty of Medicine, University of J.J.Strossmayer Osijek, Osijek, Croatia; \\ ${ }^{3}$ Emergency medicine, University Hospital Center Osijek, Osijek, Croatia
}

\section{Summary}

Immune checkpoint inhibitors, such as CTLA-4 inhibitors (ipilimumab), PD-1 (nivolumab, pembrolizumab), and PDL1 inhibitors (atezolizumab, durvalumab) have become standard in the treatment of numerous malignant tumors.

Immunotherapy blocks the body's natural protective measures with immune checkpoint inhibitors. It prevents immune over-activation, but it can also affect normal tissue, and cause autoimmune side effects. They cover a diverse spectrum of events and require different treatment approaches. Immune-related side effects can affect any organ or tissue, but most commonly affect the skin, colon, lungs, liver and endocrine organs (such as the pituitary or thyroid).

We can divide them according to the anatomical location where they cause side effects. Most of these side effects are mild to moderate and reversible if detected early and treated appropriately. The most common side effects of CTLA-4 inhibitor and PD-1 / PD-L1 inhibitor are skin symptoms (such as rash and itching). Gastrointestinal symptoms (such as diarrhea) are more common with CTLA-4 inhibitors, while lung symptoms and thyroid dysfunction occur more frequently with the use of PD-1/PD-L1 inhibitors.

It is important to determine the side effect, and the degree of the same to be able to treat it adequately. First-grade side effects are mild, second grade moderate, third grade severe, and fourth grade very severe.

Re-administration of immunotherapy after immunotherapy in patients with significant irAE (immune-related adverse events) during initial treatment with either a CTLA-4 inhibitor and/or a PD-1 / PD-L1 checkpoint inhibitor can be safely repeated after discussing and ensuring that the patient does not experience a new serious side effect.

KEYWORDS: immunotherapy, immune checkpoint inhibitors, adverse events

\section{INTRODUCTION}

Immune checkpoint inhibitors, such as CTLA-4 inhibitors (ipilimumab), PD-1 (nivolumab, pembrolizumab), and PD-L1 inhibitors (atezolizumab, durvalumab) have become standard in the treatment of numerous malignant tumors. In general, the revolution of immune checkpoint inhibitors (ICIs) was a great success, but resistance to these drugs restricts the number of patients able

Corresponding author: Ivana Canjko, Department of Oncology, University Hospital Center Osijek, J.Huttlera 4, 31000 Osijek, Croatia.e-mail address: dr.ivanamarkovic@gmail.com to achieve great responses. Also, immune-related adverse events (irAE) additionally complicate the management and treatment with immunotherapy. Because of that, we want to see effective and safe administration of ICIs therapy, with a favorable response(1-3).

\section{MECHANISM OF ACTION}

Immunotherapy blocks the body's natural protective measures with immune checkpoint inhibitors. This kind of treatment aims to enhance the host's immune response of the host and har- 
ness adaptive and innate immune responses to effectuate the long-lived elimination of diseased cells. ICIs have fewer off-target outcomes compared with chemotherapy or other treatment options that kill cancer cells directly(4).

\section{PATTERNS OF IMMUNE RESPONSE}

Even at the beginning of the development of ICIs unconventional patterns of response have been observed comparing it with normal chemotherapy or targeted therapies.

These patterns include durable response, dissociated response, pseudoprogression and hyperprogression(5). The difference between pseudoprogression and hyperprogression is basically that pseudoprogression is defined as an objective response following initial progression with the same treatment. On the other hand, hyperprogression is defined as the unexpected acceleration of tumor growth after immunotherapy administration $(6,7)$. Immunotherapy should be stopped early in cases where there is suspicion of hyperprogression. Because of that, we need to be extremely careful in distinguishing pseudoprogression from hyperprogression.

Pseudoprogression represents an unusual but favorable pattern of response to immunotherapy. It should be identified as quickly as possible in order not to interrupt an efficient treatment too early. However, typical progression is more common than pseudoprogression and the decision to pursue immunotherapy beyond progression should only be made in patients with an evident clinical benefit from immunotherapy $(8,9)$. These unconventional responses were described as progression based on standard RECIST, new immunotherapy-specific radiologic criteria were developed, such as immune-related response criteria (irRC), immune-related RECIST (irRECIST), immune RECIST (iRE- CIST) and immune-modified RECIST (imRECIST)(6,10-12). Also, one of the patterns of immune response is durable response. No standard definition of durable response exists but since ICIs stimulate a cancer-specific immune response, responses to immunotherapy should be durable, even after stopping the treatment. Yet another type of response seen with immunotherapy drugs is the phenomena of dissociated responses.
This means that some areas of the tumor may decrease with the treatment,whereas other areas may continue to grow in size(5).

\section{IMMUNE-RELATED ADVERSE EVENTS (IRAES) AND THEIR MANAGEMENT}

Immunotherapy prevents immune over-activation, but it can also affect normal tissue and cause autoimmune side effects. They cover a diverse spectrum of events and require different treatment approaches. Immune-related side effects can affect any organ or tissue, but most commonly they affect the skin, colon, lungs, liver and endocrine organs (such as the pituitary or thyroid)(13).

We can divide them according to the anatomical location where they cause the side effect (Table 1.)(14-20). Side effects after treatment with immune checkpoint inhibitors usually occur within a few weeks or months of starting the treatment, but can occur at any time during the treatment - as early as a few days after the first infusion, but sometimes even 1 year after the end of treatment. The most common side effects of CTLA-4 inhibitor and PD-1 / PD-L1 inhibitor are skin symptoms (such as rash 15\% - 24\% and itching 13\% - 35\%). Gastrointestinal symptoms (such as diarrhea 27\% - 54\%) are more common with CTLA-4 inhibitors, while lung symptoms and thyroid dysfunction occur more frequently with the use of PD-1 / PD-L1 inhibitors. Fatigue is one of the common side effects with anti-PD $1(16 \%-37 \%)$ and anti-PDL 1 $(12 \%-24 \%)$ inhibitors while its pathogenesis stays unclear and only a small number of cases can be attributed to hypothyroidism. Treatment with the combinations of CTLA-4 inhibitors and PD- 1 is more likely to cause side effects) $(1,2)$. For ipilimumab irAEs are dermatological, gastrointestinal, and renal toxicities. On the other hand, for pembrolizumab they are arthralgia, pneumonitis, and hepatic toxicities. Nivolumab can cause endocrine toxicities, and hypothyroidism is most common for atezolizumab(21-24).

Most of these side effects are mild to moderate and reversible if detected early and treated appropriately. The treatment of immunological side effects can be divided into the general principle of treatment and special recommendations considering the affected organ. It is important to determine the side effect, and the degree of the same to be 


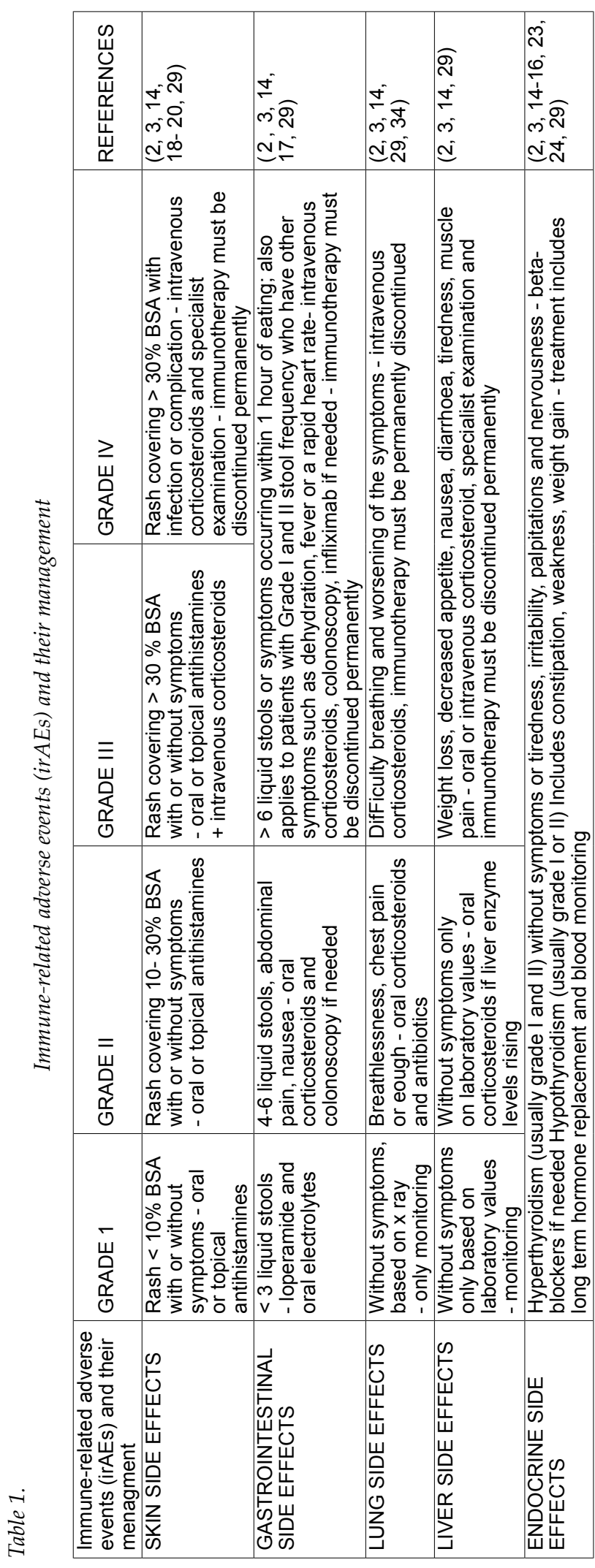

able to treat it adequately. The grade of the toxicity can be determined by CTCAE classification. Treatment predominantly depends on the grade of toxicity and the organ that is affected. Some organizations have developed therapeutic algorithms that help and simplify effective diagnosis and treatment of adverse effects such as ASCO, the National Comprehensive Cancer Network, the European Society of Medical Oncology, the Society for Immunotherapy of Cancer, and the European League against Rheumatism.

First-grade side effects are mild, second grade moderate, third grade severe, and fourth grade very severe. The principles for the management of side effects associated with immune checkpoint inhibitors generally include treatment of first and second-grade symptoms, without interruption or permanent cessation of immunotherapy treatment. Patients with persistent second-grade symptoms may need to skip one or more doses of treatment. They also need to be treated until their symptoms are alleviated or resolved with corticosteroids (prednisone $0.5 \mathrm{mg} /$ $\mathrm{kg}$ /day or equivalent)(25,26). Exceptions are second-grade thyroid dysfunction side effects, which can be treated with replacement therapy without interruption of immunotherapy. With third or fourth-grade symptoms treatment is in most cases discontinued and the patient is treated with high doses of intravenous corticosteroids $(1-2 \mathrm{mg} / \mathrm{kg} /$ day or equivalent) in hospital setting. Also, the patient is referred to a specialist depending on the affected organ. Patients that benefit from corticosteroid therapy usually improve their condition within 3 days. In those patients who do not improve on steroid therapy, infliximab $5 \mathrm{mg} / \mathrm{kg}$ is introduced rather than continuing corticosteroid therapy. Infliximab is not used in patients with increased liver function tests because it causes hepatotoxicity $(2,27)$.

To conclude, patients with CTCAE grade 1 irAEs typically do not require treatment and, in most cases, ICIs can be continued or temporarily stopped. On the other hand, patients with grade 2 adverse effects should stop ICIs until adverse effects drop off. In some particular cases, patients with grade 2 adverse effects can consider administrating glucocorticoids depending on the severity of the organ-specific damage or if irAEs persist after ICI therapy is stopped. And patients present- 
ing with grade 3 or grade 4 irAEs should initially receive steroids. In general, patients' oncologists can treat grade 1 irAEs, but, patients with grade 2 or higher irAEs or those with symptomatic endocrine irAEs such as diabetes mellitus or thyroid disease should be referred to a specialist. For some organ-specific irAEs (pancreatitis, hypophysitis, pneumonitis, neurological, rheumatic, and systemic autoimmune diseases), referral to a specialist should be strongly considered regardless of CTCAE severity(28-32).

The association between the incidence of irAE and the antitumor efficacy of immunotherapy is somewhat controversial. Some studies suggest that irAE correlates with improved response and survival rate, while others have failed to show such association. Further studies are needed to confirm if the experience of irAE is also a prediction of treatment outcomes(32-35). The use of corticosteroids or other immunosuppressants, according to the available data, does not significantly affect the efficacy of immune checkpoint inhibitors(36). However, for patients who plan to re-administer immunotherapy after experiencing irAE, concomitant administration of immunosuppressive therapies is associated with reduced efficacy of immunotherapy.

Prophylaxis for Pneumocystis pneumonia (PCP) is recommended to patients receiving glucocorticoids for an irAE in the setting of combined chemotherapy plus immunotherapy; to those with underlying pulmonary conditions receiving glucocorticoids for an uncomplicated irAE; or to those with a complicated irAE (eg, those requiring longer than six weeks of glucocorticoids or additional immunosuppressive therapy).

Re-administration of immunotherapy after immunotherapy in patients with significant irAE during initial treatment with either a CTLA-4 inhibitor and/or a PD-1 / PD-L1 checkpoint inhibitor can be safely repeated after discussing and ensuring no new severe harm occurs. The choice to repeat immunotherapy depends on several factors: the severity and the nature of the initial irAE, the response to systemic immunosuppression, the clinical response to the initial immunotherapy regimen and the availability of alternative treatment options. Data on the effectiveness of this approach are limited and further clinical studies are needed to confirm it.

\section{CONCLUSION}

Immune checkpoint inhibitors, such as CTLA4 inhibitors (ipilimumab), PD-1 (nivolumab, pembrolizumab), and PD-L1 inhibitors (atezolizumab, durvalumab) have become standard in the treatment of numerous malignant tumors. Because immunotherapy will be used more and more in the future, we must understand its mechanism of action, patterns of the immune response, and most importantly how to notice and adequately treat all the side effects of immunotherapy.

\section{REFERENCES}

1. Bagchi S, Yuan R, Engleman EG. Immune checkpoint inhibitors for the treatment of cancer: clinical impact and mechanisms of response and resistance. Annu Rev Pathol. 2021;16:223-49.

2. Management of immunotherapy-related toxicities NCCN version 4.2021 2021. Available from: https: //www.nccn.org/login?ReturnURL=https://www . nccn.org/professionals/physician_gls/pdf/immunotherapy.pdf.

3. Haanen JBAG, Carbonel F, Robert C, Kerr K.M, Peters $\mathrm{S}$, Larkin J, et al. Management of toxicities from immunotherapy: ESMO clinical practice guidelines for diagnosis, treatment and follow-up. Ann Oncol 2017; 28(suppl.4)iv119-iv142.

4. Thommen DS, Schumacher TN. T cell dysfunction in cancer. Cancer Cell. 2018;33(4):547-62.

5. Borcoman E, Kanjanapan Y, Champiat S, Kato S, Servois V, Kurzrock R, et al. Novel patterns of response under immunotherapy. Ann Oncol. 2019;30(3):385-96.

6. Wolchok JD, Hoos A, O'Day S, Weber JS, Hamid O, Lebbé $\mathrm{C}$, et al. Guidelines for the evaluation of immune therapy activity in solid tumors: immune-related response criteria. Clin Cancer Res. 2009;15(23): 7412-20.

7. Champiat S, Dercle L, Ammari S, Massard C, Hollebecque A, Postel-Vinay $S$, et al. Hyperprogressive disease is a new pattern of progression in cancer patients treated by anti-PD-1/PD-L1. Clin Cancer Res. 2017; 23(8):1920-8.

8. Chiou VL, Burotto M. Pseudoprogression and immune-related response in solid tumors. J Clin Oncol. 2015;33(31):3541-3.

9. Frelaut M, du Rusquec P, de Moura A, Le Tourneau C, Borcoman E. Pseudoprogression and hyperprogression as new forms of response to immunotherapy. BioDrugs. 2020;34(4):463-76.

10. Hodi FS, Hwu WJ, Kefford R, Weber JS, Daud A, Hamid $\mathrm{O}$, et al. Evaluation of immune-related response criteria and RECIST v1.1 in patients with advanced melanoma treated with pembrolizumab. J Clin Oncol. 2016;34(13):1510-7. 
11. Seymour L, Bogaerts J, Perrone A, Ford R, Schwartz LH, Mandrekar S, et al. iRECIST: guidelines for response criteria for use in trials testing immunotherapeutics. Lancet Oncol. 2017;18(3):e143-e52.

12. Hodi FS, Ballinger M, Lyons B, Soria JC, Nishino M, Tabernero J, et al. Immune-modified response evaluation criteria in solid tumors (imRECIST): refining guidelines to assess the clinical benefit of cancer immunotherapy. J Clin Oncol. 2018;36(9):850-8.

13. Martins F, Sofiya L, Sykiotis GP, Lamine F, Maillard M, Fraga M, et al. Adverse effects of immune-checkpoint inhibitors: epidemiology, management and surveillance. Nat Rev Clin Oncol. 2019;16(9):563-80.

14. Patient guide on immunotherapy-related side effects and their management 2021. Available from: https:// www.esmo.org/for-patients/patient-guides/immunotherapy-side-effects.

15. Corsello SM, Barnabei A, Marchetti P, De Vecchis L, Salvatori R, Torino F. Endocrine side effects induced by immune checkpoint inhibitors. J Clin Endocrinol Metab. 2013;98(4):1361-75.

16. Agrawal L, Bacal A, Jain S, Singh V, Emanuele N, Emanuele $\mathrm{M}$, et al. Immune checkpoint inhibitors and endocrine side effects, a narrative review. Postgrad Med. 2020;132(2):206-14.

17. Špaček J. Gastrointestinal toxicity of immunotherapy. Klin Onkol. 2020;33(1):23-8.

18. Sibaud V. Dermatologic reactions to immune checkpoint inhibitors : skin toxicities and immunotherapy. Am J Clin Dermatol. 2018;19(3):345-61.

19. Anadkat MJ, Cowen EW. Immunotherapy and skin side effects. JAMA Dermatol. 2018;154(6):744.

20. Lacouture M, Sibaud V. Toxic side effects of targeted therapies and immunotherapies affecting the skin, oral mucosa, hair, and nails. Am J Clin Dermatol. 2018;19(Suppl 1):31-9.

21. Haratani K, Hayashi H, Chiba Y, Kudo K, Yonesaka K, Kato R, et al. Association of immune-related adverse events with nivolumab efficacy in non-small-cell lung cancer. JAMA Oncol. 2018;4(3):374-8.

22. Darnell EP, Mooradian MJ, Baruch EN, Yilmaz M, Reynolds KL. Immune-related adverse events (irAEs): diagnosis, management, and clinical pearls. Curr Oncol Rep. 2020;22(4):39.

23. Ferrari SM, Fallahi P, Galetta F, Citi E, Benvenga S, Antonelli A. Thyroid disorders induced by checkpoint inhibitors. Rev Endocr Metab Disord. 2018;19(4): 325-33.

24. Barroso-Sousa R, Barry WT, Garrido-Castro AC, Hodi FS, Min L, Krop IE, et al. Incidence of endocrine dysfunction following the use of different immune checkpoint inhibitor regimens: a systematic review and meta-analysis. JAMA Oncol. 2018;4(2):173-82.
25. Indini A, Rijavec E, Grossi F. Immune related adverse events and response to immunotherapy: Focus on corticosteroids. Lung Cancer. 2020;145:225.

26. Kroschinsky F, Stölzel F, von Bonin S, Beutel G, Kochanek M, Kiehl M, et al. New drugs, new toxicities: severe side effects of modern targeted and immunotherapy of cancer and their management. Crit Care. 2017;21(1):89.

27. Som A, Mandaliya R, Alsaadi D, Farshidpour M, Charabaty A, Malhotra N, et al. Immune checkpoint inhibitor-induced colitis: A comprehensive review. World J Clin Cases. 2019;7(4):405-18.

28. Puzanov I, Diab A, Abdallah K, Bingham CO $3^{\text {rd }}$, Brogdon C, Dadu R, et al. Managing toxicities associated with immune checkpoint inhibitors: consensus recommendations from the Society for immunotherapy of cancer (SITC) toxicity management working group. J Immunother Cancer. 2017;5(1):95.

29. Thompson JA, Schneider BJ, Brahmer J, Andrews S, Armand P, Bhatia S, et al. Management of immunotherapy-related toxicities, Version 1.2019. J Natl Compr Canc Netw. 2019;17(3):255-89.

30. Brahmer JR, Lacchetti C, Schneider BJ, Atkins MB, Brassil KJ, Caterino JM, et al. Management of immunerelated adverse events in patients treated with immune checkpoint inhibitor therapy: American society of clinical oncology clinical practice guideline. J Clin Oncol. 2018;36(17):1714-68.

31. Kostine M, Finckh A, Bingham CO, Visser K, Leipe J, Schulze-Koops $\mathrm{H}$, et al. EULAR recommendations for the diagnosis and the management of rheumatic immune-related adverse events due to cancer immunotherapy. Ann Oncol 2019;30(suppl.5):V528.

32. Ramos-Casals M, Brahmer JR, Callahan MK, FloresChávez A, Keegan N, Khamashta MA, et al. Immunerelated adverse events of checkpoint inhibitors. Nat Rev Dis Primers. 2020;6(1):38.

33. Fiala $\mathrm{O}$, Šorejs $\mathrm{O}$, Šustr J, Fínek J. Side effects and efficacy of immunotherapy. Klin Onkol. 2020;33(1):8-10.

34. Suresh K, Naidoo J, Lin CT, Danoff S. Immune checkpoint immunotherapy for non-small cell lung cancer: benefits and pulmonary toxicities. Chest. 2018;154 (6):1416-23.

35. Hussaini S, Chehade R, Boldt RG, Raphael J, Blanchette $P$, Maleki Vareki S, et al. Association between immune-related side effects and efficacy and benefit of immune checkpoint inhibitors - A systematic review and meta-analysis. Cancer Treat Rev. 2021;92:102134.

36. Aldea M, Orillard E, Mansi L, Marabelle A, Scotte F, Lambotte $\mathrm{O}$, et al. How to manage patients with corticosteroids in oncology in the era of immunotherapy? Eur J Cancer. 2020;141:239-51. 


\section{Sažetak}

\section{TOKSIČNOST IMUNOTERAPIJE}

\section{Canjko, L. Perić, J. Flam, M. Kovač Barić, D. Kotromanović, N. Pušeljić, M. Šambić Penc}

Inhibitori imunoloških kontrolnih točaka, poput CTLA-4 inhibitora (ipilimumab), PD-1 (nivolumab, pembrolizumab) i PD-L1 inhibitora (atezolizumab, durvalumab) postali su standardni u liječenju brojnih malignih tumora.

Imunoterapija blokira prirodne zaštitne mjere tijela inhibitorima imunoloških kontrolnih točaka. Sprječava imunološku pretjeranu aktivaciju, ali može utjecati i na normalno tkivo i uzrokovati autoimune nuspojave. Oni pokrivaju raznolik spektar događaja i zahtijevaju različite pristupe u liječenju. Imunološke nuspojave mogu utjecati na bilo koji organ ili tkivo, ali najčešće zahvaćaju kožu, debelo crijevo, pluća, jetru i endokrine organe (poput hipofize ili štitnjače).

Možemo ih podijeliti prema anatomskom mjestu gdje izazivaju nuspojavu. Većina ovih nuspojava blaga je do umjerena i reverzibilna ako se rano otkrije i liječi na odgovarajući način. Najčešće nuspojave inhibitora CTLA-4 i inhibitora PD-1 / PD-L1 su nuspojave kože (poput osipa i svrbeža). Gastrointestinalni simptomi (poput proljeva) češći su kod inhibitora CTLA-4, dok se plućni simptomi i disfunkcija štitnjače češće javljaju uz upotrebu inhibitora PD-1 / PD-L1.

Važno je utvrditi nuspojavu i stupanj iste kako biste ju mogli adekvatno liječiti. Nuspojave prvog stupnja su blage, drugog stupnja umjerene, trećeg stupnja teške i četvrtog vrlo teške.

Ponovna primjena imunoterapije nakon imunoterapije u bolesnika sa značajnim irAE (imunološki povezane nuspojave) tijekom početnog liječenja bilo inhibitorom CTLA-4 i / ili inhibitorom kontrolne točke PD-1 / PD-L1 može se sigurno ponoviti nakon isključivanja mogućnosti ponovnog povratka ozbiljne nuspojave.

KLJUČNE RIJEČI: imunoterapija, inhibitori imunoloških kontrolnih točaka, nuspojave 